\title{
Allopurinol reduces antigen-specific and polyclonal activation of human $\mathrm{T}$ cells
}

\author{
Damián Pérez-Mazliah ${ }^{1 *}{ }^{\dagger}$, María C. Albareda ${ }^{1}$, María G. Alvarez $^{2}$, Bruno Lococo ${ }^{2}$, \\ Graciela L. Bertocchi ${ }^{2}$, Marcos Petti ${ }^{2}$, Rodolfo J. Viotti ${ }^{2}$ and Susana A. Laucella ${ }^{1}$ \\ 1 Instituto Nacional de Parasitología "Dr. Mario Fatala Chaben," Ciudad Autónoma de Buenos Aires, Argentina \\ 2 Sección Enfermedad de Chagas, Hospital Interzonal General de Agudos "Eva Perón," San Martín, Provincia de Buenos Aires, Argentina
}

\section{Edited by:}

Janos G. Filep, University

of Montreal, Canada

Reviewed by:

Fulvio D'Acquisto, Queen Mary

University of London, UK

Shinjiro Hamano, Nagasaki

University, Japan

*Correspondence:

Damián Pérez-Mazliah, Division of Parasitology, MRC National Institute for Medical Research, Division of Parasitology, The

Ridgeway, London NW7 1AA, UK. e-mail:dmazlia@nimr.mrc.ac.uk

${ }^{\dagger}$ Present address:

Damián Pérez-Mazliah, Division

of Parasitology, MRC National

Institute for Medical Research, The

Ridgeway, London NW7 1AA, UK.
Allopurinol is the most popular commercially available xanthine oxidase inhibitor and it is widely used for treatment of symptomatic hyperuricaemia, or gout. Although, several anti-inflammatory actions of allopurinol have been demonstrated in vivo and in vitro, there have been few studies on the action of allopurinol on T cells. In the current study, we have assessed the effect of allopurinol on antigen-specific and mitogen-driven activation and cytokine production in human T cells. Allopurinol markedly decreased the frequency of IFN- $\gamma$ and IL-2-producing T cells, either after polyclonal or antigen-specific stimulation with Herpes Simplex virus 1, Influenza (Flu) virus, tetanus toxoid and Trypanosoma cruzi-derived antigens. Allopurinol attenuated CD69 upregulation after CD3 and CD28 engagement and significantly reduced the levels of spontaneous and mitogen-induced intracellular reactive oxygen species in T cells. The diminished T cell activation and cytokine production in the presence of allopurinol support a direct action of allopurinol on human $\mathrm{T}$ cells, offering a potential pharmacological tool for the management of cell-mediated inflammatory diseases.

Keywords: allopurinol, T cells, xanthine oxidase, Th1 cytokines, anti-inflammatory

\section{INTRODUCTION}

Allopurinol is the most popular commercially available xanthine oxidase inhibitor. This molecule and its in vivo active metabolite oxypurinol act as hypoxanthine analogs that irreversibly inhibit xanthine oxidase leading to an inhibition of the catalytic reaction that generates uric acid from hypoxanthine and xanthine, with the concomitant production of superoxide $\left(\mathrm{O}_{2}^{-}\right)$and hydrogen peroxide $\left(\mathrm{H}_{2} \mathrm{O}_{2}\right)$ (Elion, 1988). Since its approval by the Food and Drug Administration in 1966, allopurinol has been used for treatment of symptomatic hyperuricaemia, or gout (Pacher et al., 2006). However, allopurinol presents a wide range of other potential therapeutic applications such as chronic kidney disease, ischemic reperfusion injury, ischemic heart disease, hypertension, chronic heart failure (Pacher et al., 2006), vascular endothelial dysfunction (George and Struthers, 2009), lens-induced uveitis (Augustin et al., 1994, 1996) and chemotherapy of parasitic infections such as leishmaniasis and Chagas disease (Apt et al., 2005; Harzallah et al., 2010). It was also demonstrated that allopurinol reduces rejection in renal transplant recipients when combined with azathioprine/cyclosporine/prednisolone regimens (Chocair et al., 1993).

Abbreviations: 7-AAD, 7-aminoactinomycin D; AL, allopurinol; DCF, $2^{\prime} 7^{\prime}$ dichlorofluorescein; DCFH-DA, $2^{\prime} 7^{\prime}$-dichlorofluorescin di-acetate; DV, drug vehicle; HSV-1, herpes simplex virus-1; iROS, intracellular reactive oxygen species; PBMC, peripheral blood mononuclear cells; PMA, Phorbol 12-myristate 13acetate; T. cruzi, Trypanosoma cruzi.
Several anti-inflammatory actions of allopurinol have been demonstrated in vivo and in vitro, probably related with its dose-dependent free radical scavenging ability (Namazi, 2004). Allopurinol decreases the production of Tumor Necrosis Factor- $\alpha$ by human mononuclear cells (Oláh et al., 1994), downregulates the expression of Intercellular Adhesion Molecule 1 (ICAM-1 or CD54) and $\mathrm{P}_{2} \mathrm{X}_{7}$ purinergic receptor on human monocytes/macrophages (Mizuno et al., 2004), decreases antigen-specific B cell responses in Ovalbumin-immunized BALB/c mice (Kato et al., 2000) and blocks the induction of Monocyte Chemotactic Factor-1 and Interleukin-6 production in rat vascular smooth muscle cells (Lee et al., 2005). However, the action of allopurinol on $\mathrm{T}$ cells is less known. In this regard, allopurinol has been reported to significantly suppress phytohaemagglutin-induced lymphocyte blastogenesis (Kurashige et al., 1985). As allopurinol is a widely prescribed drug with immunomodulatory action and has been proposed as a good candidate for treatment of inflammatory-mediated diseases in which T cells are involved (Grus et al., 2003; Govani and Higgins, 2010), it would be of interest to clarify any putative capacity of allopurinol to modulate $\mathrm{T}$ cell activation. Herein, we show that allopurinol diminishes activation as well as cytokine and intracellular reactive oxygen species production by $\mathrm{T}$ cells following antigen specific or mitogen-driven stimulation of human peripheral blood mononuclear cells (PBMC). 


\section{MATERIALS AND METHODS SELECTION OF STUDY POPULATION}

Healthy adult volunteers $(n=21)$ aged $27-53$ years and asymptomatic chronically Trypanosoma cruzi-infected adult subjects $(n=7)$ aged $38-52$ years living in urban areas of Buenos Aires, Argentina, were recruited at the Hospital Interzonal General de Agudos "Eva Peron" Buenos Aires, Argentina. Subjects with hypertension, ischemic heart disease, cancer, HIV infection, syphilis, diabetes, arthritis, or serious allergies were excluded from the present study. This protocol was approved by the Institutional Review Board of the Hospital Interzonal General de Agudos "Eva Peron." Signed informed consents were obtained from all individuals before inclusion in the study, and are stored by the authors.

\section{COLLECTION OF HUMAN PBMC}

Blood samples were obtained by venipuncture and PBMC were isolated by density gradient centrifugation on Ficoll-hypaque (Amershan, Sweden) and were cryopreserved for later analysis.

\section{DRUGS AND ANTIGENS}

Allopurinol was purchased from USP/BP, Italy. Whole viral particles from Herpes Simplex virus 1 (HSV-1), strain F, were kindly provided by Dr. Carlos A Pujol (Laboratorio de Virología, Departamento de Química Biológica, Universidad de Buenos Aires, Argentina) and obtained as described elsewhere (Matsuhiro et al., 2005). Briefly, HSV-1 strain F was originally obtained from the American Type Culture Collection (Rockville, USA) and propagated in Vero (African green monkey kidney) cells grown in Eagle's minimum essential medium (EMEM, Sigma, USA) supplemented with $1.5 \%$ calf serum in $150 \mathrm{~cm}^{2}$ cell culture flasks (BD Falcon, USA). Supernatant from HSV-1-infected Vero cell cultures was titrated by plaque formation and used as antigenic stimulation. Supernatant from non-infected Vero cell cultures did not induce $\mathrm{T}$ cell responses in ELISPOT assays with PBMC. Peptides derived from Influenza (Flu) virus with high binding affinity for the common class I HLA-supertypes A01, A02, A03, B27, and B35 were synthesized at the University of Georgia Molecular Genetics Instrumentation Facility (Athens, USA). A commercial vaccine (Tetanol Pur, ELEA, Novartis, Germany) was used as an antigen source for tetanus toxoid. An amastigote lysate preparation derived from the Brazil strain of Trypanosoma cruzi (T. cruzi) was obtained as previously described (Laucella et al., 2004).

\section{DETERMINATION OF ALLOPURINOL CYTOTOXICITY}

Three $\times 10^{6}$ PBMC were incubated in 24 -well plates in complete RPMI 1640 10\% fetal calf serum in the presence or absence of allopurinol in a concentration range from 25 to $300 \mu \mathrm{g} / \mathrm{ml}$ or drug vehicle $(10 \mathrm{mM} \mathrm{NaOH})$ during 2, 24 or $48 \mathrm{~h}$ at $37^{\circ} \mathrm{C}$. The frequency of total viable and nonviable $\mathrm{CD} 8^{+}, \mathrm{CD}^{+}$, and $\mathrm{CD} 14^{+}$cells were determined by staining with $1 \mu \mathrm{g} / \mathrm{ml} 7$-Aminoactinomycin $\mathrm{D}$ (7-AAD) in combination with anti-human CD8 (APC), anti-human CD4 (PE) and anti-human CD14 (FITC) antibodies (Becton Dickinson, USA) for $30 \mathrm{~min}$ at $4^{\circ} \mathrm{C}$. Cells were then washed, fixed with $2 \%$ paraformaldehyde and acquired in a FacsCalibur flow cytometer (Becton Dickinson, USA). Analysis was performed with FlowJo software (Tree Star, USA). At least $5 \times 10^{5}$ events were collected per sample.

\section{IFN- $\gamma$ AND INTERLEUKIN 2 ENZYME-LINKED IMMUNOSORBENT SPOT (ELISPOT) ASSAYS}

The number of antigen-specific Interferon-gamma (IFN- $\gamma$ )secreting or interleukin-2 (IL-2)-secreting $\mathrm{T}$ cells for the different stimuli assessed was determined by ex vivo ELISPOT using commercial kits (ELISPOT Human IFN- $\gamma$ and IL-2 Sets; Becton Dickinson, USA), as described by the manufacturer. Cryopreserved PBMC were seeded in triplicate wells, at a concentration of $4 \times 10^{5}$ cells/well, and were stimulated with HSV-1 (at a multiplicity of infection of 10 plaque forming units/cell), Flu-derived peptide pool $(1 \mu \mathrm{g} / \mathrm{ml} /$ peptide $)$, tetanus toxoid $(1 / 20$ dilution) or T. cruzi lysate $(10 \mu \mathrm{g} / \mathrm{ml})$ in the presence of drug vehicle alone $(10 \mathrm{mM} \mathrm{NaOH})$ or allopurinol $(300 \mu \mathrm{g} / \mathrm{ml}$ in $10 \mathrm{mM}$ $\mathrm{NaOH}$ ) for $18-20 \mathrm{~h}$. Stimulation of PBMC with $20 \mathrm{ng} / \mathrm{ml}$ Phorbol 12-myristate 13-acetate (PMA, Sigma, USA) plus $500 \mathrm{ng} / \mathrm{ml}$ Ionomycin (Sigma, USA) in media was used as positive control of cytokine secretion, while PBMC incubated in media with the addition of allopurinol or drug vehicle served to determine the basal levels of spot-forming cells. For set-up of experimental conditions, $4 \times 10^{5} \mathrm{PBMC}$ were stimulated with $100 \mathrm{ng} / \mathrm{ml}$ of anti-CD3 in combination with $100 \mathrm{ng} / \mathrm{ml}$ of anti-CD28 antibodies (Becton Dickinson, USA) in the presence of drug vehicle alone or different allopurinol concentrations for 18-20 h. Spots were counted and analyzed by Analyzer and ImmunoSpot software (version 6.5; CTL, USA). Responses were considered positive if the number of spot-forming cells in the presence of antigen was at least twice the number of spots in the presence of media, and the number of spots in the latter was less than 10 per $4 \times 10^{5}$ cells. The number of specific IFN- $\boldsymbol{\gamma}$ and IL-2-secreting T cells was calculated by subtracting the value of the wells containing media alone from the antigen/mitogen-stimulated spot count. Only subjects that presented positive antigen-specific responses were included in these assays.

\section{CD69 SURFACE EXPRESSION}

Cryopreserved PBMC were incubated over night at $37^{\circ} \mathrm{C}$ in 24-well plates in complete RPMI 1640 10\% fetal calf serum at a density of $10^{6}$ cells $/ \mathrm{ml}$. Cells were then stimulated with $1 \mu \mathrm{g} / \mathrm{ml}$ of anti-CD3 in combination with $1 \mu \mathrm{g} / \mathrm{ml}$ of anti-CD28 antibodies (Becton Dickinson, USA) in the presence of drug vehicle alone or $300 \mu \mathrm{g} / \mathrm{ml}$ allopurinol during $5 \mathrm{~h}$. PBMC cultured with complete RPMI in the presence of drug vehicle alone or $300 \mu \mathrm{g} / \mathrm{ml}$ allopurinol served as unstimulated control cells. Then, the cells were washed and stained with anti-human CD4 (PerCP), anti-human CD8 (APC) and anti-human CD69 (PE) (Becton Dickinson, USA) for $30 \mathrm{~min}$ at $4^{\circ} \mathrm{C}$. At least $5 \times 10^{5}$ events were collected per sample in a FacsCalibur flow cytometer (Becton Dickinson, USA). Analysis was performed with FlowJo software (Tree Star, USA).

\section{INTRACELLULAR REACTIVE OXYGEN SPECIES (iROS) DETERMINATION}

iROS levels were determined as described previously (Yano et al., 1998). Briefly, cryopreserved PBMC were thawed and $1 \times$ $10^{6}$ PBMC were stained with anti-human CD3 APC (Becton 
Dickinson, USA) in PBS for $15 \mathrm{~min}$ at room temperature. Cells were then washed and further incubated with $100 \mathrm{nM} \mathrm{2}$ $7^{\prime}$-dichlorofluorescin di-acetate (DCFH-DA, Sigma, USA) for $15 \mathrm{~min}$ at $37^{\circ} \mathrm{C}$ and shaking, with or without $300 \mu \mathrm{g} / \mathrm{ml}$ allopurinol in PBS. In this case, allopurinol was directly dissolved into PBS to avoid the use of drug vehicle. Thereafter, $100 \mathrm{nM}$ PMA or PBS alone was added to the culture for additional $1 \mathrm{hr}$ at $37^{\circ} \mathrm{C}$ under shaking. Cells were acquired in a FacsCalibur flow cytometer (Becton Dickinson, USA) and analyzed with FlowJo software (Tree Star, USA). At least $2 \times 10^{5}$ events were collected per sample. The intracellular hydrolyzed and oxidized form, $2^{\prime}$ $7^{\prime}$-dichlorofluorescein (DCF), was detected at the FL-1 channel. DCF mean fluorescence intensity represents a measure of iROS.

\section{STATISTICAL ANALYSIS}

The Kruskal-Wallis nonparametric test was used to compare the percentages of surface markers expression and 7-AAD incorporation in PBMC treated with different concentrations of allopurinol or drug vehicle. The Wilcoxon signed rank test was applied to compare the frequencies and sizes of spot-forming cells, CD69 expression and iROS production between untreated and allopurinol-treated PBMC. Differences were considered to be statistically significant at $P<0.05$.

\section{RESULTS}

\section{In vitro TREATMENT WITH ALLOPURINOL EXERTS NO CYTOTOXICITY AND HAS NO INFLUENCE ON CD4, CD8, AND CD14 EXPRESSION}

In order to rule-out any possible cytotoxic effect of allopurinol on human PBMC, cell viability was evaluated by staining with 7-AAD, a nucleic acid fluorescent dye that penetrates the cell membrane of nonviable cells and allows the quantification of dying or dead cells by flow cytometry. Allopurinol did not affect either cell viability (Figures 1A-D) or the constitutive expression of CD4, CD8, and CD14, regardless the dose (Figures 1E-G) in a $48 \mathrm{~h}$ assay. Neither significant difference in cell viability or in the expression of surface markers was recorded after 2 or $24 \mathrm{~h}$-incubation in the presence of allopurinol (data not shown).

\section{ALLOPURINOL DECREASES POLYCLONAL PRODUCTION OF IFN- $\gamma$ AND IL-2 BY HUMAN PBMC}

We have evaluated the effect of allopurinol on the ability of human $\mathrm{T}$ cells to secrete IFN- $\gamma$ and IL- 2 after stimulation with different pathogen-specific antigens. Considering that previous studies have shown that treatment of human PBMC with allopurinol in a range of $25-100 \mu \mathrm{g} / \mathrm{ml}$ impairs several monocyte functions (Mizuno et al., 2004), experimental conditions for cytokine secretion by the ELISPOT technique were set-up by stimulation of PBMC with anti CD3/CD28 antibodies in the presence of $25-300 \mu \mathrm{g} / \mathrm{ml}$ allopurinol. Although decreases in both IFN- $\gamma$ (Figures 2A-C) and IL-2 (Figures 2E-G) production were already observed at $100 \mu \mathrm{g} / \mathrm{ml}$ allopurinol, these decreases became significant with $300 \mu \mathrm{g} / \mathrm{ml}$ allopurinol. Thus, the latter concentration was chosen for further studies. Drug vehicle alone did not exert any effect on cytokine production (Figures 2D and $\mathbf{H}$ ).

\section{In vitro TREATMENT WITH ALLOPURINOL ATTENUATES ACTIVATION-DRIVEN CD69 EXPRESSION IN HUMAN T CELLS}

CD69 is a cell surface molecule upregulated early after $\mathrm{T}$ cell activation (Hara et al., 1986; Cosulich et al., 1987; Risso et al., 1989). In this study, we also evaluated the effect of allopurinol on early events of human $\mathrm{T}$ cell activation by measuring alterations in CD69 expression. As shown in Figure 3, allopurinol attenuates CD69 upregulation on $\mathrm{CD}^{+}$(Figure 3A and top panels Figure $3 \mathrm{C}$ ) and $\mathrm{CD}^{+}$(Figure $3 \mathbf{B}$ and bottom panels Figure 3C) $\mathrm{T}$ cells after anti-CD3/CD28 stimulation. The mean fold increase in CD69 expression after anti-CD3/CD28 stimulation was $38 \%$ and $30 \%$ lower in the presence of allopurinol for $\mathrm{CD}^{+}{ }^{+}$and $\mathrm{CD}^{+}{ }^{+} \mathrm{T}$ cells, respectively, compared with drug vehicle alone. Conversely, neither allopurinol nor the drug vehicle altered the expression of CD69 on unstimulated T cells after the 5 h-incubation period (Figures 3A-C).

\section{In vitro TREATMENT WITH ALLOPURINOL REDUCES IROS PRODUCTION IN HUMAN T CELLS}

$\mathrm{T}$ cells increase the production of ROS early after activation and their effector function is strongly regulated by ROS, through distinct $\mathrm{T}$ cell receptor (TCR) pathways (Devadas et al., 2002; Williams and Kwon, 2004; Yan and Banerjee, 2010). Taking into account that allopurinol is a potent scavenger of ROS (Moorhouse et al., 1987) and presents antioxidant activities in vivo (Augustin et al., 1994), we hypothesized that allopurinol action on $\mathrm{T}$ cell activation could be explained by its scavenging action during early activation events of T cells. We therefore studied the allopurinol action on iROS production in human T cells by measuring DCF mean fluorescence intensity in response to PMA, a known stimulus for iROS production in human T cells (Yano et al., 1998). Allopurinol significantly reduced either the levels of spontaneous (Figures 4A and B) or PMA-induced (Figures 4A and C) iROS in total $\mathrm{T}$ cells.

\section{ALLOPURINOL DECREASES ANTIGEN-SPECIFIC IFN- $\gamma$ AND IL-2-PRODUCING T CELL RESPONSES IN HUMAN PBMC}

The effect of allopurinol on antigen-specific cytokine production by $\mathrm{T}$ cells was also evaluated. To achieve this aim, $\mathrm{T}$ cell responses specific for pathogen-derived antigens representative of different infection models, including a chronic viral infection (HSV-1), a solved viral infection (Flu) and a parasitic chronic infection (T. cruzi) were measured ex vivo by IFN- $\gamma$ and IL-2 ELISPOT assays. $\mathrm{T}$ cell responses specific for Tetanus toxoid were also analyzed in a group of vaccinated subjects. Allopurinol markedly decreased the frequency of IFN- $\gamma$-producing $\mathrm{T}$ cells independently of the antigen used as stimuli, including full viral particles from HSV-1, a Flu-derived peptide pool with high binding affinity for common class I HLA-supertypes, tetanus toxoid and a T. cruzi lysate preparation (Figures 5A-D). Likewise, IL-2 production was also diminished in the presence of allopurinol upon stimulation with T. cruzi antigens (Figure 5E). The mean spot size of IFN- $\gamma$ was significantly decreased in the presence of allopurinol, indicating not only a reduction in the frequency of IFN- $\gamma$-producing $\mathrm{T}$ cells, but also in cytokine production at a single cell level (Figures 6A and B). As seen after polyclonal stimulation, drug vehicle alone did not have any effect on cytokine 


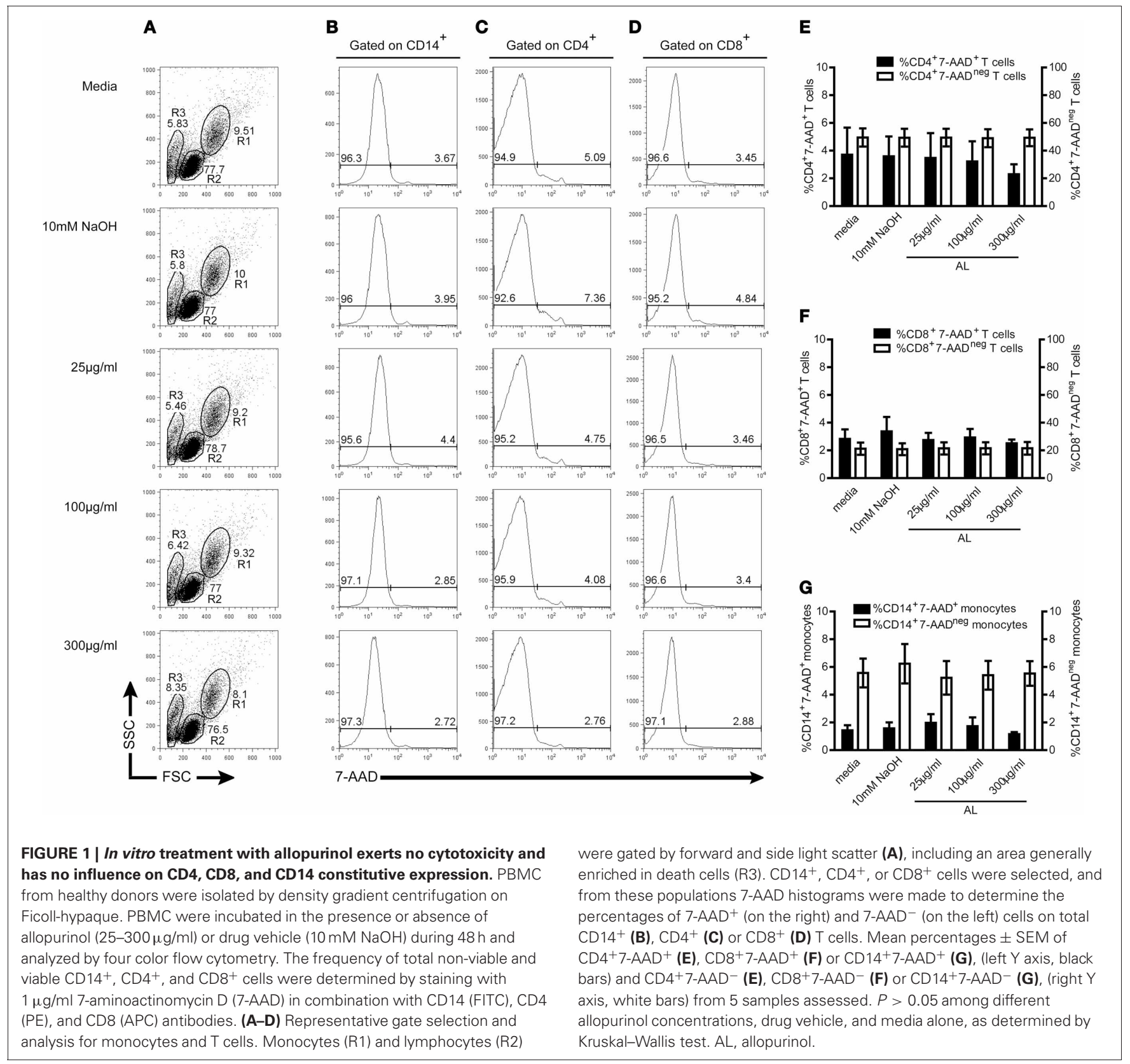

production after antigen-specific stimulation (Figures 5A-E and Figures 6A and $B$ ).

\section{DISCUSSION}

Xanthine Oxidase inhibitors have emerged as therapeutic tools for inflammatory-mediated diseases, including those in which $\mathrm{T}$ cells are involved (Grus et al., 2003; Pacher et al., 2006; Govani and Higgins, 2010; Ng et al., 2011; Sliem and Nasr, 2011). In the present study, the effect of allopurinol on late (i.e., cytokine production) as well as on early (i.e., CD69 expression and iROS production) events of human $\mathrm{T}$ cell activation was investigated. We show, for the first time, that allopurinol decreases class I and class II-restricted antigen-specific and polyclonal IFN- $\gamma$ and IL-2 production, in addition to the expression of activation markers by human T cells.

Antigen-specific activation of $\mathrm{T}$ cells requires recognition of peptide-MHC complexes by the TCR on antigen presenting cells, costimulation and the expression of adhesion molecules. The recognition of antigen by the TCR initiates transcriptional activation of particular genes that mediate $\mathrm{T}$ cell responses. We found that allopurinol decreased IFN- $\gamma$ production by $\mathrm{T}$ cells specific for different pathogens probably due to a direct effect of the drug on $\mathrm{T}$ cells as well as on antigen-presenting cells. This view is supported by other findings showing that allopurinol downregulates the expression of ICAM-1 on monocytes (Mizuno et al., 2004) and modulates protein kinase C activity 


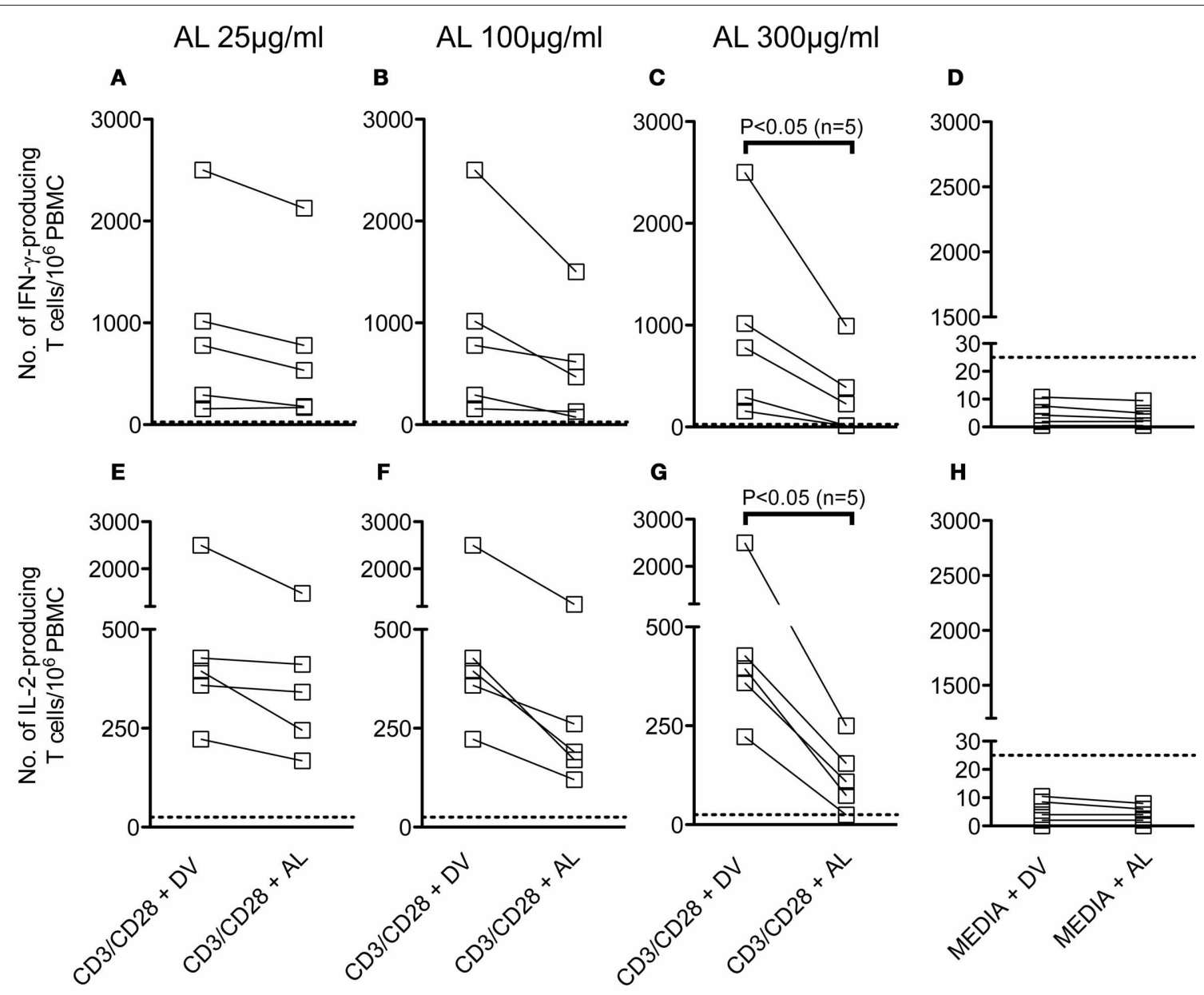

FIGURE 2 | Effect of different concentrations of allopurinol on polyclonal activation-driven IFN $\boldsymbol{\gamma}$ and IL-2 production by human T cells. PBMC from healthy donors were stimulated with anti-CD3 $(100 \mathrm{ng} / \mathrm{ml})$ plus anti-CD28 $(100 \mathrm{ng} / \mathrm{ml})$ antibodies, or remained with media alone, in the presence of different concentrations of allopurinol ( $+A L)$ or drug vehicle (+DV), for 18-20 $\mathrm{h}$ and the number of IFN- $\gamma$-secreting (A-D) or IL-2-secreting (E-G) $T$ cells were determined by ex vivo ELISPOT assays. (D and $\mathbf{H}$ ) The samples were cultured in media with the addition of $A L$ or DV. Each line represents an individual subject. Panels $\mathbf{A}-\mathbf{C}$ and $\mathbf{E}-\mathbf{G}$ show the net number of spot-forming cells (spot-forming cells in media were subtracted). Dotted lines represent the threshold for positive IFN- $\gamma$ or IL-2 ELISPOT responses, as defined in Materials and Methods. Comparisons between T cell responses in the absence or presence of allopurinol upon stimulation were performed by Wilcoxon signed rank test.
(Kang et al., 2006), one of the main enzymes involved in biochemical pathways inducing $\mathrm{T}$ cell responses. IFN- $\gamma$ secretion was also reduced in the presence of allopurinol after polyclonal stimulation of $\mathrm{T}$ cells with anti-CD3/CD28 that mimics signals generated by the TCR complex, bypassing the need for T cellantigen presenting cell interaction, supporting that allopurinol might exert a direct action on $\mathrm{T}$ cells. Moreover, we showed that IL-2 production, a cytokine that drives T cell activation, is reduced in the presence of allopurinol. The lower amounts of antigen-specific cytokine production, as evidenced by the smaller spot size and the attenuation of CD69 upregulation upon activation with $\mathrm{CD} 3 / \mathrm{CD} 28$, further support the specific effect of allopurinol on $\mathrm{T}$ cell activation.

Diverse evidences have shown that the redox state can influence $\mathrm{T}$ cell function in vitro and in vivo (Griffiths et al., 2011). Cross-linking of the TCR and the co-stimulatory molecule CD28 in human $\mathrm{T}$ cells results in enhanced iROS production that is needed for NF-кB and IL-2 expression (Los et al., 1995) and is consistent with an important role for ROS in the immediate early events during activation (Yan and Banerjee, 2010). Lipid metabolism, mitochondria, and/or NADPH oxidases have been claimed to be the source of iROS during $\mathrm{T}$ cell activation (Williams and Kwon, 2004). Although xanthine oxidase also mediates ROS generation, this enzyme is not expressed by human immune cells (Dröge, 2002). Xanthine oxidase is distributed in the liver, gut, lung, kidney, heart, and brain, accounting for only a minor proportion of total ROS production under normal conditions (Dröge, 2002). Thus, the modulation of $\mathrm{T}$ cell function observed herein would be accounted for the ROS scavenging action of allopurinol but not for an inhibition in ROS production mediated by the xanthine oxidase enzyme. Thus, allopurinol would deprive $\mathrm{T}$ cells from iROS which are required during the early activation of the NF-kB complex (Los et al., 1995) and PKC (Kang et al., 2006), thus promoting a 


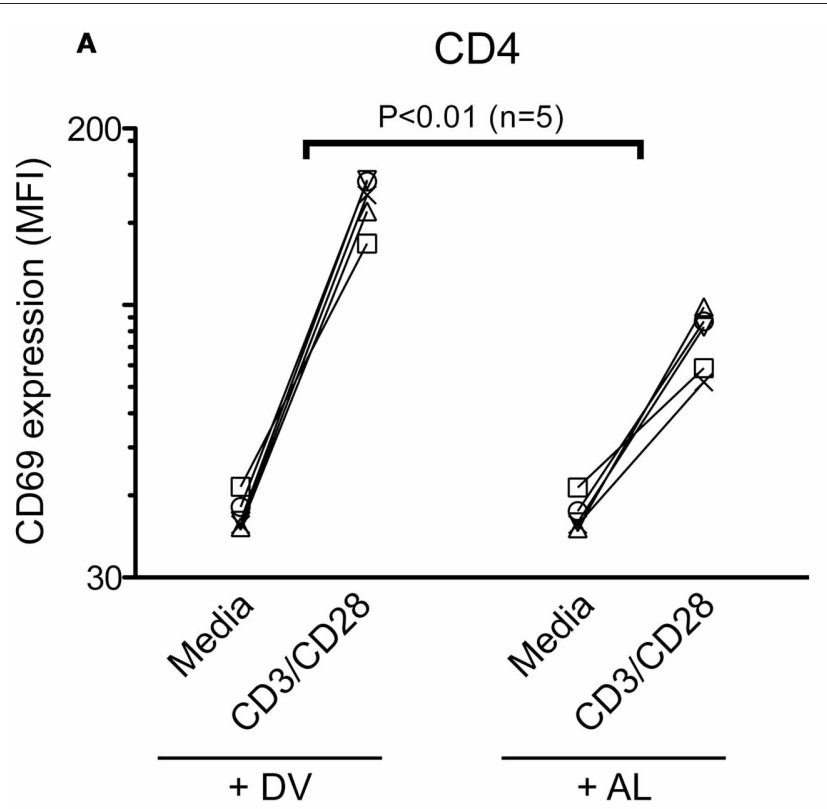

B

CD8

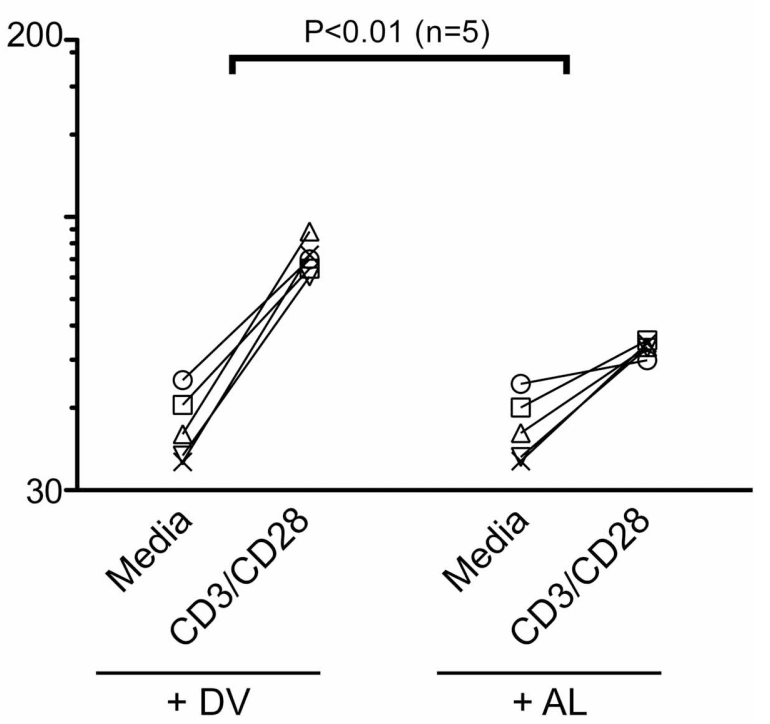

C

Gated on CD4 ${ }^{+}$
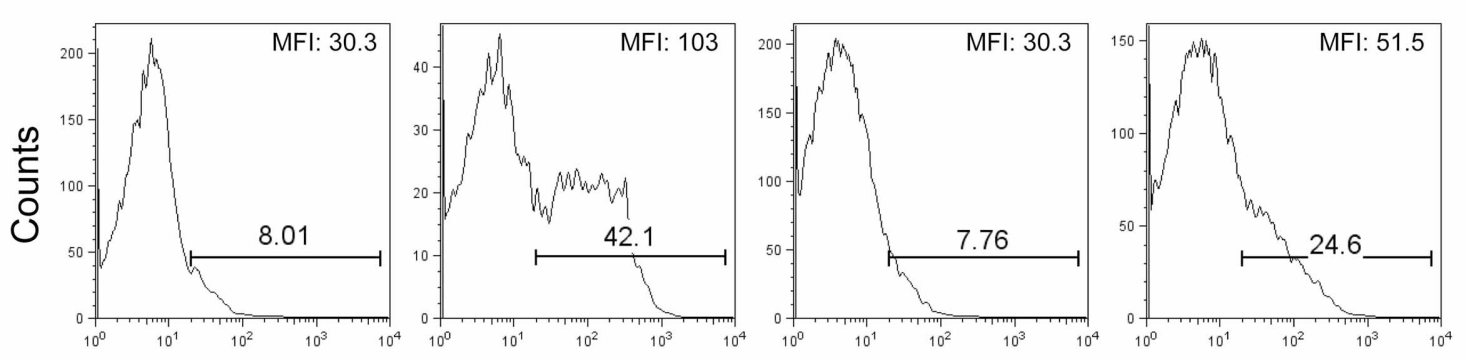

Gated on CD8 ${ }^{+}$
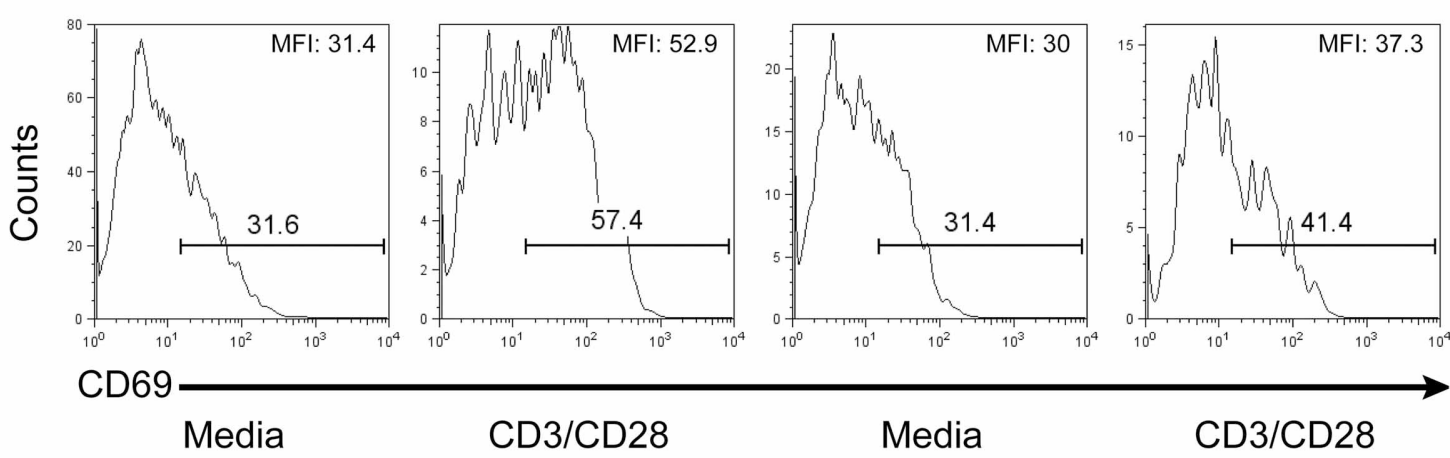

$\mathrm{CD} 3 / \mathrm{CD} 28$

$+\mathrm{DV}$

Media

\section{$\mathrm{CD} 3 / \mathrm{CD} 28$}

$+\mathrm{AL}$

FIGURE 3 | Allopurinol attenuates activation-driven CD69 upregulation in $\mathrm{CD4}^{+}$and $\mathrm{CD8}^{+} \mathbf{T}$ cells. PBMC were incubated for $5 \mathrm{~h}$ with media or with anti-CD3 $(1 \mu \mathrm{g} / \mathrm{ml})$ plus anti-CD28 $(1 \mu \mathrm{g} / \mathrm{ml})$ antibodies, in the presence of allopurinol (+ AL, $300 \mu \mathrm{g} / \mathrm{ml}$ ) or drug vehicle alone (+DV). Cells were then stained with anti-CD4 (PerCP), anti-CD8 (APC) and anti-CD69 (PE) and analyzed with four color flow cytometry. Lymphocytes were gated by forward and side light scatter. From this population single color CD4 or CD8 staining histogram was made, and the expression of CD69 was analyzed. Each line shows the mean fluorescence intensity (MFI) of CD69 expression on $\mathrm{CD}^{+}(\mathrm{A})$ or $\mathrm{CD}^{+}$
(B) T cells before and following stimulation with anti-CD3/CD28 antibodies, in the presence of drug vehicle (+ DV) or allopurinol (+ AL), for each subject evaluated. Comparisons between the differences in net CD69 expression (subtracting CD69 MFI in media) with and without allopurinol were performed by Wilcoxon signed rank test. Representative histogram plots of $\mathrm{CD} 69$ expression on $\mathrm{CD}^{+}$(C, top panels) and $\mathrm{CD}^{+}$(C) bottom panels) $T$ cells with the indicated treatment. The numbers over the bars indicate the percentages of $\mathrm{CD}_{69}{ }^{+}$cells and the numbers in the top right corner indicate the MFI of $\mathrm{CD} 69$ expression on $\mathrm{CD}_{4}^{+}$(top) and $\mathrm{CD}^{+}{ }^{+}$(bottom) T cells. 


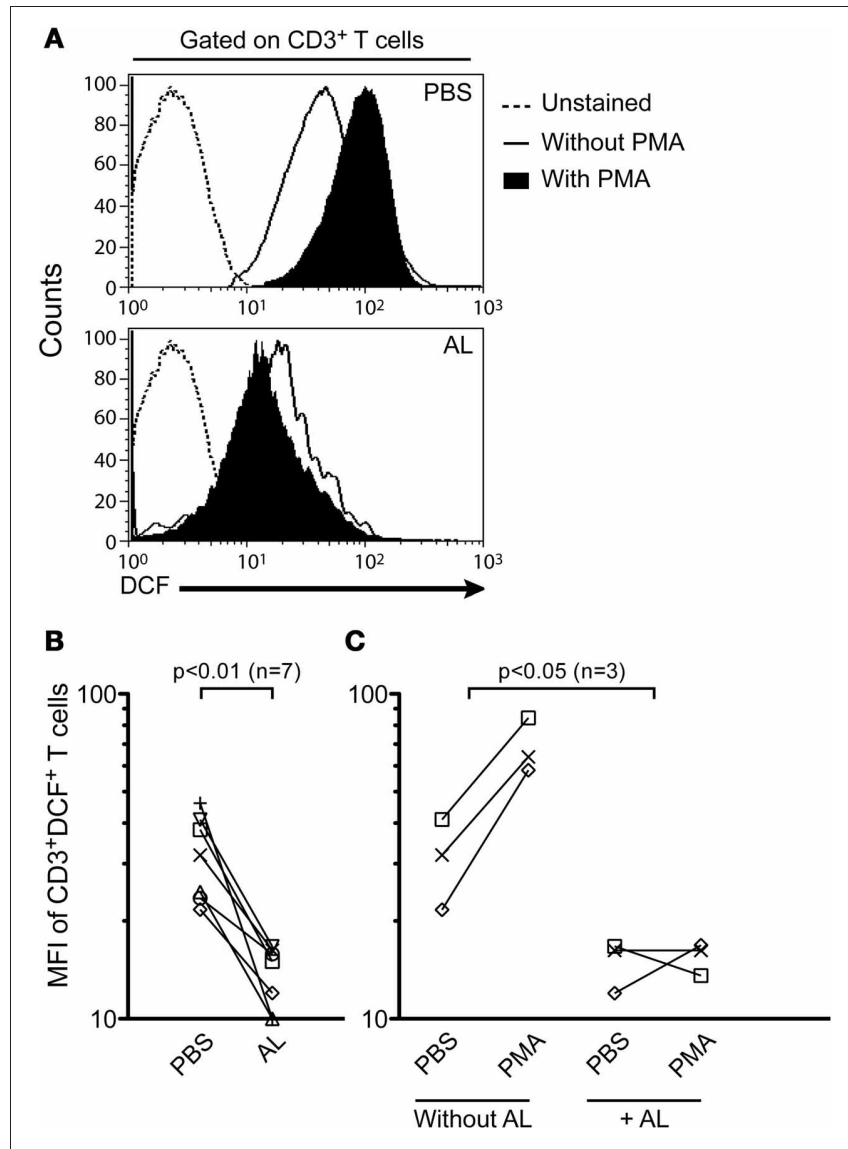

FIGURE 4 | Allopurinol attenuates spontaneous and mitogen-activated iROS production in human T cells. PBMC were stained with anti-CD3 PE and incubated at $37^{\circ} \mathrm{C}$ for $1 \mathrm{~h}$ with DCFH-DA and PBS alone or with PMA $(100 \mathrm{nM})$ in the presence $(+\mathrm{AL}, 300 \mu \mathrm{g} / \mathrm{ml})$ or absence of allopurinol. The oxidized form, DCF represents a measure of iROS. Lymphocytes were gated by forward and side light scatter. From this population single color CD3 staining histogram was made, and the expression of DCF in the gated population was analyzed. (A) Representative iROS expression on $\mathrm{CD}^{+} \mathrm{T}$ cells in the absence (upper panel) or presence (bottom panel) of allopurinol. (B) Cumulative data of spontaneous iROS production from 7 subjects. Each line represents spontaneous iROS levels for each patient in the absence (PBS) or in the presence (AL) of allopurinol. (C) Cumulative data of induced iROS production. Each line show iROS release for each subject prior and following stimulation with PMA in the presence $(+A L)$ or absence of allopurinol. Comparisons were performed by Wilcoxon signed rank test. $\mathrm{MFI}$ : mean fluorescence intensity.

hyporesponsive state of $\mathrm{T}$ cells. In agreement with this notion, allopurinol has been recently shown to reduce NF- $\mathrm{B}$ pathway activation, pro-inflammatory cytokines production, and oxidative stress in different in vivo models of inflammation (CorreaCosta et al., 2011; Aldaba-Muruato et al., 2012; Demirel et al., 2012).

Both T cells and dendritic cells elevate the intracellular oxidation status upon antigen-specific interaction, and bidirectional dendritic cell-T cell communication can be blocked by interfering with redox regulation pathways (Matsue et al., 2003). Moreover, alteration in redox status of $\mathrm{T}$ cells and dendritic cells has been recently proposed as a putative mechanism of regulatory $\mathrm{T}$ cells action (Yan et al., 2010). Although, we cannot rule out the possibility that the effect of allopurinol on antigen-specific $\mathrm{T}$ cell responses is due to, at least partially, an impairment in antigen presentation by the action of allopurinol on antigen-presenting cells, the reduction of iROS production by PMA-stimulated T cells in the presence of allopurinol for short periods of time further supports the idea of a direct action of allopurinol on $\mathrm{T}$ cell activation. Future studies regarding the effect of allopurinol on the expression of costimulatory molecules, as well as studies at the transcriptional level on T cells, will help us to further clarify these ideas.

$\mathrm{CD}^{+}{ }^{+}$IFN- $\gamma$-producing $\mathrm{T}_{\mathrm{h} 1}$ cells have long been associated with the pathogenesis of many organ-specific autoimmune diseases (Dardalhon et al., 2008). Herein, we report that these responses might be inhibited by allopurinol, in vitro. A beneficial effect of allopurinol on cell-mediated diseases is also supported by an improvement of the response to thiopurine treatment by the addition of allopurinol in individuals with inflammatory

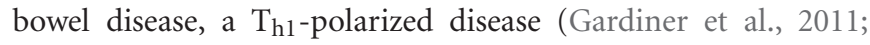
Smith et al., 2012). Inflammation has also been pointed out as a potential target for therapy of chronic heart failure (Celis et al., 2008), that has been strongly correlated with $\mathrm{T}$ cell activation and altered $\mathrm{T}_{\mathrm{h} 1} / \mathrm{T}_{\mathrm{h} 2}$ balance (Cheng et al., 2009). iROS production by phagocytic leukocytes is also increased in heart failure patients (Castro et al., 2003) and it is a major cause of endothelial dysfunction as iROS can act both, as triggers or amplifiers of the inflammatory response (Deschamps and Spinale, 2006; Castro et al., 2008). Several studies have demonstrated that treatment with xanthine oxidase inhibitors of patients suffering from heart failure resulted in reduced oxidative stress and improved endothelial function (Landmesser et al., 2002; Castro et al., 2005; Hare et al., 2008). Our results showed that allopurinol decreases iROS production by $\mathrm{T}$ cells which might have important therapeutic implications since down-regulation of inflammatory $\mathrm{T}$ cells is the treatment of choice for many inflammatory diseases. In agreement with this notion, the use of a different immunomodulating agent, Pentoxifylline, improved the clinical status of patients with idiopathic-dilated and ischemic cardiomyopathy (Barnett and Touchon, 1990; Skudicky et al., 2000; Sliwa et al., 2002, 2004).

Allopurinol is rapidly absorbed in vivo, reaching peak plasma concentrations within 30-60 min, following oral administration (Pea, 2005). Allopurinol has relatively short half-life in plasma (2$3 \mathrm{~h}$ ) because it is rapidly metabolized in vivo and converted almost completely into to the oxidized metabolite, oxypurinol, which has the same therapeutic pattern but a much longer elimination halflife (14-30 h) than the parent compound (Pea, 2005). Allopurinol is negligibly bound to plasma proteins, and gets spread to different tissues, including vascular tissue, liver, intestine, and heart (Murrell and Rapeport, 1986). Therefore, the maximum possible concentration of allopurinol in vivo is hard to estimate, making it difficult to predict the in vivo physiological relevance of drug concentrations applied, in vitro, in the present study. Moreover, it has been demonstrated that allopurinol can be differentially metabolized in vitro and in vivo (Kramer and Feldman, 1977).

Determination of plasma concentrations of oxypurinol highly differs depending on the population studied, the dose and 


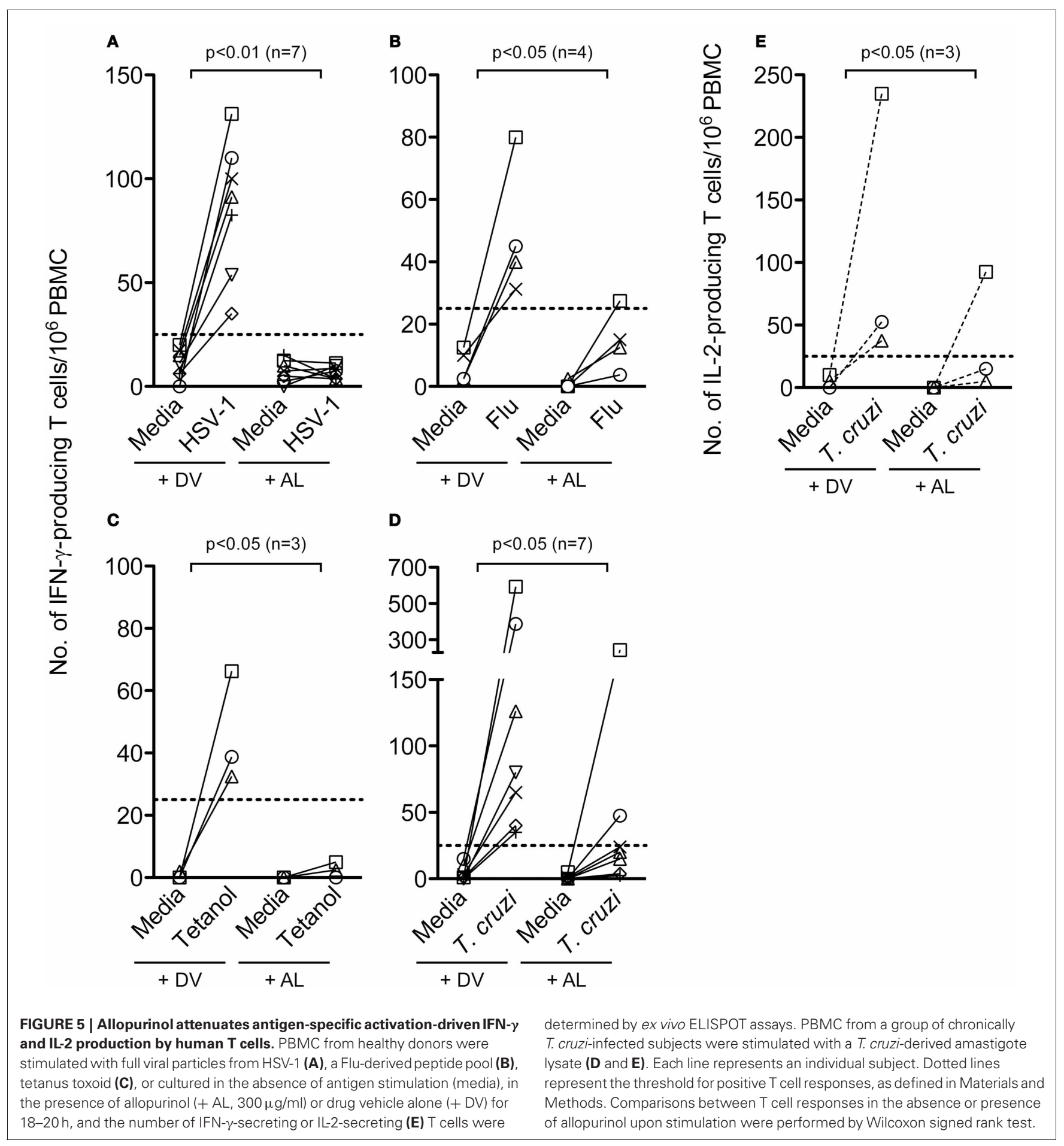

the route of administration, the length of treatment and the time-points after drug intake chosen for measurements (Rodnan et al., 1975; Breithaupt and Tittel, 1982; Berlinger et al., 1985; Murrell and Rapeport, 1986; Emmerson et al., 1987; Day et al., 1988a,b; Graham et al., 1996; Turnheim et al., 1999; Guerra et al., 2001; Kaya et al., 2006; Panomvana et al., 2008; Stocker et al., 2008; Van Dijk et al., 2008; Torrance et al., 2009; Stamp et al., 2011). For instance, Van Dijk et al. demonstrated that allopurinol reaches a mean maximal plasma concentration of $41.90 \mu \mathrm{g} / \mathrm{ml}$ within minutes after a dose of $15 \mathrm{mg} / \mathrm{kg}$ body weight administered i.v. in pregnant sows (Van Dijk et al., 2008). In a survey studying 50 adult patients receiving variable daily doses of allopurinol, with $83 \%$ of the patients taking $300 \mathrm{mg} /$ day, during $6 \pm 7.5$ years on average, a wide range of plasma oxypurinol concentration (i.e., from 2.8 to $55.8 \mu \mathrm{g} / \mathrm{ml}$ ) was observed (Day et al., 1988b). Differences in the levels of 


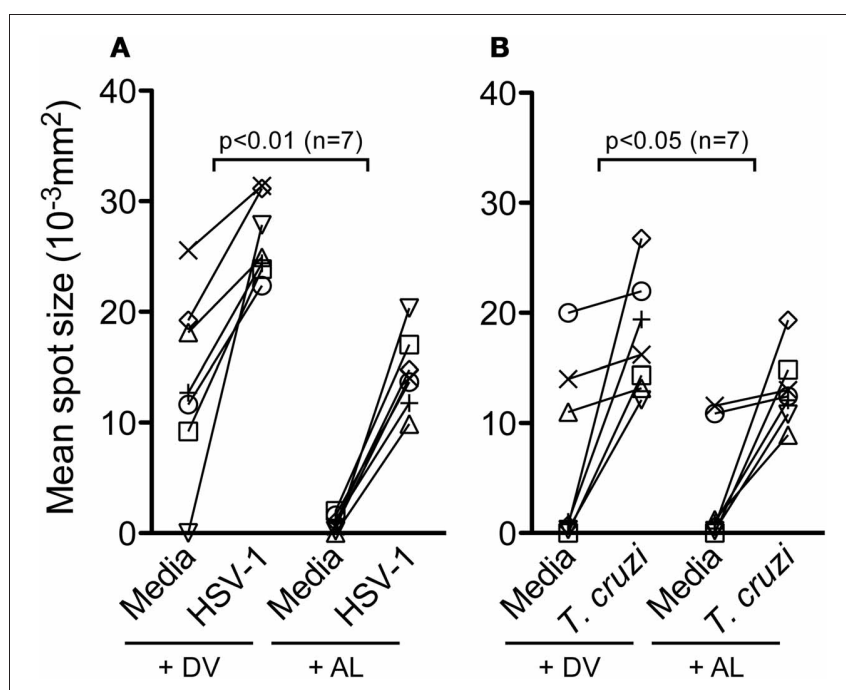

FIGURE 6 | Allopurinol decreases IFN- $\gamma$ secretion at a single cell level. IFN- $\gamma$ ELISPOT assays were performed by stimulation, or not (media), of PBMC from healthy donors with full viral particles from HSV-1 (A), or PBMC from a group of chronically T. cruzi-infected subjects with a T. cruzi-derived amastigote lysate (B), in the presence of allopurinol (+ AL, $300 \mu \mathrm{g} / \mathrm{ml})$ or drug vehicle (+ DV), for 18-20 h. Mean spot sizes represent an estimate of IFN- $\gamma$ production per cell. Each line represents an individual subject. Comparisons between $T$ cell responses in the absence or presence of allopurinol upon stimulation were performed by Wilcoxon signed rank test.

serum oxypurinol from patient to patient taking the same dose of allopurinol may result from differences in absorption, rate of metabolism, xanthine oxidase levels, the amount of drug bound to xanthine oxidase in the tissues and/or renal function. Even diet and exercise can significantly alter the pharmacokinetics of oxypurinol (Berlinger et al., 1985; Kaya et al., 2006).

In the present work, we observed that a single dose of $100 \mu \mathrm{g} / \mathrm{ml}$ allopurinol decreased $\mathrm{T}$ cell production of cytokines within hours after in vitro culture, but reaching a statistical significant reduction upon treatment with $300 \mu \mathrm{g} / \mathrm{ml}$ of allopurinol. As oxypurinol accumulates and reaches a steady-state level during long-term administration (Murrell and Rapeport, 1986), the effect of allopurinol observed within hours after in vitro culture is probably only comparable to the effect observed in subjects receiving long-term treatment with allopurinol. In this regard, allopurinol is generally well tolerated, allowing long-term treatments and administration of high doses (Momeni and Aminjavaheri, 1995; Momeni et al., 2002).

Allopurinol, administered at $600 \mathrm{mg} /$ day during 3 months, constitutes a second line drug for the treatment of chronic Chagas disease, caused by Trypanosoma cruzi infection. Allopurinol was also shown to be safe and effective in the treatment of Chagas disease reactivation after heart transplantation (Almeida et al., 1996; Bestetti and Theodoropoulos, 2009). In a recent pilot study of a sequential combined treatment with allopurinol and benznidazole in the chronic phase of Trypanosoma cruzi infection (Pérez-Mazliah et al., 2012), we have observed that the frequency of peripheral naïve $\mathrm{CD} 4^{+}$and $\mathrm{CD} 8^{+} \mathrm{T}$ cells, that are generally diminished in this phase of the infection (Albareda et al., 2006, 2009), is improved along with a decrease in the frequency of peripheral $\mathrm{CD} 4^{+}$and $\mathrm{CD} 8^{+} \mathrm{T}$ cells expressing the activation marker HLA-DR after completion of allopurinol administration. These changes were sustained following the consecutive treatment with benznidazole, supporting the immunomodulating activity of allopurinol, in vivo, on human T cells.

Allopurinol hypersensitivity syndromes, like the StevensJohnson syndrome, is an infrequent but life-threatening adverse effect that affects about $0.4 \%$ patients receiving allopurinol therapy (Arellano and Sacristán, 1993; Pluim et al., 1998) and whose mechanisms remain unclear. Three potential factors involved in allopurinol hypersensitivity syndromes are the genetic background, dose accumulation, and immunological responses to the drug. However, a relationship between the appearance of allopurinol hypersensitivity syndromes and the use of high doses has not been demonstrated (George et al., 2006). Risk factors for development of allopurinol hypersensitivity syndromes include aging, renal impairment, diuretic use, and some ethnics groups (Chinese descent) (Lee et al., 2008). In the same pilot study mentioned above (Pérez-Mazliah et al., 2012), the use of allopurinol in doses of $600 \mathrm{mg} /$ day for 90 consecutive days was very well tolerated and we did not observe any case of severe adverse reaction. This observation is in agreement with previous studies (Gallerano et al., 1990; Momeni and Aminjavaheri, 1995; Apt et al., 1998; Momeni et al., 2002; Apt et al., 2003, 2005), in which doses even higher than $1 \mathrm{~g} /$ day of allopurinol during months were administered without registering high incidence of adverse effects.

The immunomodulatory action of allopurinol described in the present work in combination with previous observations could raise the idea that allopurinol would favor the occurrence of opportunistic infections. We have not observed a higher incidence of opportunistic infections in chronically Trypanosoma cruziinfected patients under treatment with doses of $600 \mathrm{mg}$ per day of allopurinol during 3 months (Pérez-Mazliah et al., 2012). This is again in accordance with previous observations, even in longterm and high dose treatments with allopurinol (Gallerano et al., 1990; Momeni and Aminjavaheri, 1995; Apt et al., 1998, 2003, 2005; Momeni et al., 2002). Thus, the immunomodulatory effect of allopurinol does not seem to generate the level of immunosuppression required to favor opportunistic infections in vivo, at least in the context of the studies cited herein.

Nonetheless, due to its low frequent but potentially severe side effects as well as its immunomodulatory action, it is highly recommended a close follow-up of patients receiving allopurinol throughout the entire duration of the treatment. Particular attention should be paid to those populations at high risk of developing side effects and those presenting alterations in normal immune system function. In summary, this study raise evidence in line with an immunomodulatory action of allopurinol on human $\mathrm{T}$ cells, offering a potential pharmacological tool for the management of cell-mediated inflammatory diseases. 


\section{ACKNOWLEDGMENTS}

This work was supported by Consejo Nacional de Investigaciones Científicas y Técnicas (CONICET), Argentina (PIP 372); Ministerio de Salud, Argentina and Ministerio de Salud de la Provincia de Buenos Aires, Argentina. We thank Dr. Carlos A. Pujol from the University of Buenos Aires, for kindly providing HSV-1 antigens; Roberto A. Magariños, Laboratorio de especialidades de Medicamentos N1, HIGA Eva Perón, San Martín,

\section{REFERENCES}

Albareda, M. C., Laucella, S. A., Alvarez, M. G., Armenti, A. H., Bertochi, G., Tarleton, R. L., and Postan, M. (2006). Trypanosoma cruzi modulates the profile of memory CD8+ T cells in chronic Chagas' disease patients. Int. Immunol. 18, 465-471.

Albareda, M. C., Olivera, G. C., Laucella, S. A., Alvarez, M. G., Fernandez, E. R., Lococo, B., Viotti, R., Tarleton, R. L., and Postan, M. (2009). Chronic human infection with Trypanosoma cruzi drives CD4+ $\mathrm{T}$ cells to immune senescence. J. Immunol. 183, 4103-4108.

Aldaba-Muruato, L. R., Moreno, M. G., Shibayama, M., Tsutsumi, V., and Muriel, P. (2012). Protective effects of allopurinol against acute liver damage and cirrhosis induced by carbon tetrachloride: modulation of NF- $\kappa \mathrm{B}$, cytokine production and oxidative stress. Biochim. Biophys. Acta 1820, 65-75.

Almeida, D. R., Carvalho, A. C., Branco, J. N., Pereira, A. P., Correa, L., Vianna, P. V., Buffolo, E., and Martinez, E. E. (1996). Chagas' disease reactivation after heart transplantation: efficacy of allopurinol treatment. J. Heart Lung Transplant. 15, 988-992.

Apt, W., Aguilera, X., Arribada, A., Pérez, C., Miranda, C., Sánchez, G., Zulantay, I., Cortés, P., Rodríguez, J., and Juri, D. (1998). Treatment of chronic Chagasandapos; disease with itraconazole and allopurinol. Am. J. Trop. Med. Hyg. 59, 133-138.

Apt, W., Arribada, A., Zulantay, I., Sánchez, G., Vargas, S. L., and Rodríguez, J. (2003). Itraconazole or allopurinol in the treatment of chronic American trypanosomiasis: the regression and prevention of electrocardiographic abnormalities during 9 years of follow-up. Ann. Trop. Med. Parasitol. 97, 23-29.

Apt, W., Arribada, A., Zulantay, I., Solari, A., Sánchez, G., Mundaca, K., Coronado, X., Rodríguez, J., Gil, L. C., and Osuna, A. (2005). Itraconazole or allopurinol in the treatment of chronic American trypanosomiasis: the results of clinical and parasitological examinations 11 years post-treatment. Ann. Trop. Med. Parasitol. 99, 733-741.

Arellano, F., and Sacristán, J. A. (1993). Allopurinol hypersensitivity syndrome: a review. Ann. Pharmacother. 27, 337-343.

Augustin, A. J., Böker, T., Blumenröder, S. H., Lutz, J., and Spitznas, M. (1994). Free radical scavenging and antioxidant activity of allopurinol and oxypurinol in experimental lens-induced uveitis. Invest. Ophthalmol. Vis. Sci. 35, 3897-3904.

Augustin, A. J., Spitznas, M., Sekundo, W., Koch, F., Lutz, J., Meller, D., Grus, F. H., Wegener, A., and Blumenröder, S. H. (1996). Effects of allopurinol and steroids on inflammation and oxidative tissue damage in experimental lens induced uveitis: a biochemical and morphological study. $\mathrm{Br}$. J. Ophthalmol. 80, 451-457.

Barnett, J. C., and Touchon, R. C. (1990). Therapy of ischemic cardiomyopathy with pentoxifylline. Angiology 41, 1048-1052.

Berlinger, W. G., Park, G. D., and Spector, R. (1985). The effect of dietary protein on the clearance of allopurinol and oxypurinol. N. Engl. J. Med. 313, 771-776.

Bestetti, R. B., and Theodoropoulos, T.a.D. (2009). A systematic review of studies on heart transplantation for patients with end-stage Chagas' heart disease. J. Card. Fail. 15, 249-255.

Breithaupt, B., and Tittel, M. (1982). Kinetics of allopurinol after single intravenous and oral doses. Noninteraction with benzbromarone and hydrochlorothiazide. Eur. J. Clin. Pharmacol. 22, 77-84.

Castro, P., Vukasovic, J. L., Chiong, M., Díaz-Araya, G., Alcaino, H., Copaja, M., Valenzuela, R., Greig, D., Pérez, O., Corbalán, R., and Lavandero, S. (2005). Effects of carvedilol on oxidative stress and chronotropic response to exercise in patients with chronic heart failure. Eur. J. Heart Fail. 7, 1033-1039.

for assistance with reagents and Dr. Rick Tarleton from the Center for Tropical and Emerging Global Diseases, University of Georgia, GA, USA, for kindly providing Flu-derived peptides. We also thank Dr. Jean Langhorne and Dr. Phillip Spence from the division of Parasitology, MRC National Institute for Medical Research, London, UK, for critical review of the manuscript. Susana A. Laucella and María C. Albareda are members of the Scientific Career, CONICET, Argentina.

Castro, P. F., Greig, D., Pérez, O., Moraga, F., Chiong, M., DíazAraya, G., Padilla, I., Nazzal, C., Jalil, J. E., Vukasovic, J. L., Moreno, M., Corbalán, R., and Lavandero, S. (2003). Relation between oxidative stress, catecholamines, and impaired chronotropic response to exercise in patients with chronic heart failure secondary to ischemic or idiopathic dilated cardiomyopathy. Am. J. Cardiol. 92, 215-218.

Castro, P. F., Miranda, R., Verdejo, H. E., Greig, D., Gabrielli, L. A., Alcaino, H., Chiong, M., Bustos, C., Garcia, L., Mellado, R., Vukasovic, J. L., Godoy, I., and Lavandero, S. (2008). Pleiotropic effects of atorvastatin in heart failure: role in oxidative stress, inflammation, endothelial function, and exercise capacity. J. Heart Lung Transplant. 27, 435-441.

Celis, R., Torre-Martinez, G., and Torre-Amione, G. (2008). Evidence for activation of immune system in heart failure: is there a role for anti-inflammatory therapy? Curr. Opin. Cardiol. 23, 254-260.

Cheng, X., Ding, Y., Xia, C., Tang, T., Yu, X., Xie, J., Liao, M., Yao, R., Chen, Y., Wang, M., and Liao, Y.H. (2009). Atorvastatin modulates Th1/Th2 response in patients with chronic heart failure. J. Card. Fail. 15, 158-162.

Chocair, P., Duley, J., Simmonds, H. A., Cameron, J. S., Ianhez, L., Arap, S., and Sabbaga, E. (1993). Low-dose allopurinol plus azathioprine/cyclosporin/prednisolone, a novel immunosuppressive regimen. Lancet 342, 83-84.

Correa-Costa, M., Braga, T. T., Semedo, P., Hayashida, C. Y., Bechara, L. R. G., Elias, R. M., Barreto, C. R., Silva-Cunha, C., Hyane, M. I., Gonçalves, G. M., Brum, P. C., Fujihara, C., Zatz, R., Pacheco-Silva, A., Zamboni, D. S., and Camara, N. O. S. (2011). Pivotal role of tolllike receptors 2 and 4, its adaptor molecule MyD88, and inflammasome complex in experimental tubule-interstitial nephritis. PLoS
ONE 6:e29004. doi: 10.1371/journal.pone.0029004

Cosulich, M. E., Rubartelli, A., Risso, A., Cozzolino, F., and Bargellesi, A. (1987). Functional characterization of an antigen involved in an early step of T-cell activation. Proc. Natl. Acad. Sci. U.S.A. 84, 4205-4209.

Dardalhon, V., Korn, T., Kuchroo, V. K., and Anderson, A. C. (2008). Role of Th1 and Th17 cells in organ-specific autoimmunity. J. Autoimmun. 31, 252-256.

Day, R. O., Miners, J., Birkett, D. J., Graham, G. G., and Whitehead, A. (1988a). Relationship between plasma oxipurinol concentrations and xanthine oxidase activity in volunteers dosed with allopurinol. $\mathrm{Br}$. J. Clin. Pharmacol. 26, 429-434.

Day, R. O., Miners, J. O., Birkett, D. J., Whitehead, A., Naidoo, D., Hayes, J., and Savdie, E. (1988b). Allopurinol dosage selection: relationships between dose and plasma oxipurinol and urate concentrations and urinary urate excretion. Br. J. Clin. Pharmacol. 26, 423-428.

Demirel, U., Yalnız, M., Aygün, C., Orhan, C., Tuzcu, M., Sahin, K., Ozercan, I. H., and Bahçecioğlu, I. H. (2012). Allopurinol ameliorates thioacetamide-induced acute liver failure by regulating cellular redoxsensitive transcription factors in rats. Inflammation 35, 1549-1557.

Deschamps, A. M., and Spinale, F. G. (2006). Pathways of matrix metalloproteinase induction in heart failure: bioactive molecules and transcriptional regulation. Cardiovasc. Res. 69, 666-676.

Devadas, S., Zaritskaya, L., Rhee, S. G., Oberley, L., and Williams, M. S. (2002). Discrete generation of superoxide and hydrogen peroxide by $\mathrm{T}$ cell receptor stimulation: selective regulation of mitogen-activated protein kinase activation and fas ligand expression. J. Exp. Med. 195, 59-70.

Dröge, W. (2002). Free radicals in the physiological control of cell function. Physiol. Rev. 82, 47-95. 
Elion, G. B. (1988). The Purine Path to Chemotherapy. Nobel Lecture. Research Triangle Park, NC: Burroughs Welcome Co.

Emmerson, B. T., Gordon, R. B., Cross, M., and Thomson, D. B. (1987). Plasma oxipurinol concentrations during allopurinol therapy. $\mathrm{Br}$. J. Rheumatol. 26, 445-449.

Gallerano, R. H., Marr, J. J., and Sosa, R. R. (1990). Therapeutic efficacy of allopurinol in patients with chronic Chagasandapos; disease. Am. J. Trop. Med. Hyg. 43, 159-166.

Gardiner, S. J., Gearry, R. B., Burt, M. J., Chalmers-Watson, T., Chapman, B. A., Ross, A. G., Stedman, C.a.M., Huelsen, A., and Barclay, M. L. (2011). Allopurinol might improve response to azathioprine and 6mercaptopurine by correcting an unfavorable metabolite ratio. J. Gastroenterol. Hepatol. 26, 49-54.

George, J., Carr, E., Davies, J., Belch, J. J. F., and Struthers, A. (2006). Highdose allopurinol improves endothelial function by profoundly reducing vascular oxidative stress and not by lowering uric acid. Circulation 114, 2508-2516.

George, J., and Struthers, A. D. (2009). Role of urate, xanthine oxidase and the effects of allopurinol in vascular oxidative stress. Vasc. Health Risk Manag. 5, 265-272.

Govani, S. M., and Higgins, P. D. R. (2010). Combination of thiopurines and allopurinol: adverse events and clinical benefit in IBD. J. Crohns Colitis 4, 444-449.

Graham, S., Day, R. O., Wong, H., Mclachlan, A. J., Bergendal, L., Miners, J. O., and Birkett, D. J. (1996). Pharmacodynamics of oxypurinol after administration of allopurinol to healthy subjects. $\mathrm{Br}$. J. Clin. Pharmacol. 41, 299-304.

Griffiths, H. R., Dunston, C. R., Bennett, S. J., Grant, M. M., Phillips, D. C., and Kitas, G. D. (2011). Free radicals and redox signalling in T-cells during chronic inflammation and ageing. Biochem. Soc. Trans. 39, 1273-1278.

Grus, F. H., Augustin, A. J., Loeffler, K., Lutz, J., and Pfeiffer, N. (2003). Immunological effects of allopurinol in the treatment of experimental autoimmune uveitis (EAU) after onset of the disease. Eur. J. Ophthalmol. 13, 185-191.

Guerra, P., Frias, J., Ruiz, B., Soto, A., Carcas, A., Govantes, C., Montuenga, C., and Fernández, A. (2001). Bioequivalence of allopurinol and its metabolite oxipurinol in two tablet formulations. J. Clin. Pharm. Ther. 26, 113-119.
Hara, T., Jung, L. K., Bjorndahl, J. M., and $\mathrm{Fu}$, S. M. (1986). Human T cell activation. III. Rapid induction of a phosphorylated 28 $\mathrm{kD} / 32 \mathrm{kD}$ disulfide-linked early activation antigen (EA 1) by 12-otetradecanoyl phorbol-13-acetate, mitogens, and antigens. J. Exp. Med. 164, 1988-2005.

Hare, J. M., Mangal, B., Brown, J., Fisher, C., Freudenberger, R., Colucci, W. S., Mann, D. L., Liu, P., Givertz, M. M., Schwarz, R. P., and Investigators, O.-C. (2008). Impact of oxypurinol in patients with symptomatic heart failure. Results of the OPT-CHF study. J. Am. Coll. Cardiol. 51, 2301-2309.

Harzallah, K., Belhadj, R., Jemli, B., Haloues, M., Berraies, N., Gargouri, S., Hmida, J., Battikh, R., and Manaa, J. (2010). Visceral leishmaniasis in a renal transplant recipient treated with allopurinol. Saudi J. Kidney Dis. Transpl. 21, 105-108.

Kang, S.-M., Lim, S., Song, H., Chang, W., Lee, S., Bae, S.-M., Chung, J. H., Lee, H., Kim, H.-G., Yoon, D.-H., Kim, T. W., Jang, Y., Sung, J.-M., Chung, N.-S., and Hwang, K.-C. (2006). Allopurinol modulates reactive oxygen species generation and $\mathrm{Ca} 2+$ overload in ischemia-reperfused heart and hypoxia-reoxygenated cardiomyocytes. Eur. J. Pharmacol. 535, 212-219.

Kato, C., Sato, K., Wakabayashi, A., and Eishi, Y. (2000). The effects of allopurinol on immune function in normal BALB/c and SCID mice. Int. J. Immunopharmacol. 22, 547-556.

Kaya, M., Moriwaki, Y., Ka, T., Inokuchi, T., Yamamoto, A., Takahashi, S., Tsutsumi, Z., Tsuzita, J., Oku, Y., and Yamamoto, T. (2006). Plasma concentrations and urinary excretion of purine bases (uric acid, hypoxanthine, and xanthine) and oxypurinol after rigorous exercise. Metabolism 55, 103-107.

Kramer, W. G., and Feldman, S. (1977). Apparent metabolism of allopurinol by blood-a preliminary report. Res. Commun. Chem. Pathol. Pharmacol. 18, 781-784.

Kurashige, S., Akuzawa, Y., and Mitsuhashi, S. (1985). Purine metabolic enzymes in lymphocytes. IV. Effects of enzyme inhibitors and enzyme substrates on the blastogenic responses of human lymphocytes. Scand. J. Immunol. 22, $1-7$.

Landmesser, U., Spiekermann, S., Dikalov, S., Tatge, H., Wilke, R., Kohler, C., Harrison, D. G., Hornig, B., and Drexler, H. (2002).
Vascular oxidative stress and endothelial dysfunction in patients with chronic heart failure: role of xanthine-oxidase and extracellular superoxide dismutase. Circulation 106, 3073-3078.

Laucella, S. A., Postan, M., Martin, D., Hubby Fralish, B., Albareda, M. C., Alvarez, M. G., Lococo, B., Barbieri, G., Viotti, R. J., and Tarleton, R. L. (2004). Frequency of interferongamma-producing $\mathrm{T}$ cells specific for Trypanosoma cruzi inversely correlates with disease severity in chronic human Chagas disease. J. Infect. Dis. 189, 909-918.

Lee, H. Y., Ariyasinghe, J. T., and Thirumoorthy, T. (2008). Allopurinol hypersensitivity syndrome: a preventable severe cutaneous adverse reaction? Singapore Med. J. 49, 384-387.

Lee, P.-C., Ho, I.-C., and Lee, T.-C. (2005). Oxidative stress mediates sodium arsenite-induced expression of heme oxygenase-1, monocyte chemoattractant protein-1, and interleukin-6 in vascular smooth muscle cells. Toxicol. Sci. 85, 541-550.

Los, M., Schenk, H., Hexel, K., Baeuerle, P. A., Droge, W., and Schulze-Osthoff, K. (1995). IL-2 gene expression and NF-kappa B activation through $\mathrm{CD} 28$ requires reactive oxygen production by 5-lipoxygenase. EMBO J. 14, 3731-3740.

Matsue, H., Edelbaum, D., Shalhevet, D., Mizumoto, N., Yang, C., Mummert, M. E., Oeda, J., Masayasu, H., and Takashima, A. (2003). Generation and function of reactive oxygen species in dendritic cells during antigen presentation. J. Immunol. 171 , 3010-3018.

Matsuhiro, B., Conte, A. F., Damonte, E. B., Kolender, A. A., Matulewicz, M. C., Mejías, E. G., Pujol, C. A., and Zúñiga, E. A. (2005). Structural analysis and antiviral activity of a sulfated galactan from the red seaweed Schizymenia binderi (Gigartinales, Rhodophyta). Carbohydr. Res. 340, 2392-2402.

Mizuno, K., Okamoto, H., and Horio, T. (2004). Inhibitory influences of xanthine oxidase inhibitor and angiotensin I-converting enzyme inhibitor on multinucleated giant cell formation from monocytes by downregulation of adhesion molecules and purinergic receptors. Br. J. Dermatol. 150, 205-210.

Momeni, A., Reiszadae, M., and Aminjavaheri, M. (2002). Treatment of cutaneous leishmaniasis with a combination of allopurinol and low-dose meglumine antimoniate. Int. J. Dermatol. 41, 441-443.

Momeni, A. Z., and Aminjavaheri, M. (1995). Treatment of recurrent cutaneous Leishmaniasis. Int. J. Dermatol. 34, 129-133.

Moorhouse, P. C., Grootveld, M., Halliwell, B., Quinlan, J. G. and Gutteridge, J. M. (1987). Allopurinol and oxypurinol are hydroxyl radical scavengers. FEBS Lett. 213, 23-28.

Murrell, G. A., and Rapeport, W. G. (1986). Clinical pharmacokinetics of allopurinol. Clin. Pharmacokinet. 11, 343-353.

Namazi, M. R. (2004). Cetirizine and allopurinol as novel weapons against cellular autoimmune disorders. Int. Immunopharmacol. 4, 349-353.

Ng, S. C., Chan, F. K. L., and Sung, J. J. Y. (2011). Review article: the role of non-biological drugs in refractory inflammatory bowel disease. Aliment. Pharmacol. Ther. 33, 417-427.

Oláh, T., Régely, K., and Mándi, Y. (1994). The inhibitory effects of allopurinol on the production and cytotoxicity of tumor necrosis factor. Naunyn Schmiedebergs Arch. Pharmacol. 350, 96-99.

Pacher, P., Nivorozhkin, A., and Szabó, C. (2006). Therapeutic effects of xanthine oxidase inhibitors: renaissance half a century after the discovery of allopurinol. Pharmacol. Rev. $58,87-114$

Panomvana, D., Sripradit, S., and Angthararak, S. (2008). Higher therapeutic plasma oxypurinol concentrations might be required for gouty patients with chronic kidney disease. J. Clin. Rheumatol. 14, 6-11.

Pea, F. (2005). Pharmacology of drugs for hyperuricemia. Mech. Kinet. Interact. Contrib. Nephrol. 147, 35-46.

Pérez-Mazliah, D., Álvarez, M. G., Cooley, G., Lococo, B., Bertocchi, G., Petti, M., Albareda, M. C., Armenti, A., Tarleton, R., Laucella, S., and Viotti, R. (2012). Sequential combined treatment with allopurinol and benznidazole in the chronic phase of Trypanosoma cruzi infection: a pilot study. J. Antimicrob. Chemother. (in press).

Pluim, H. J., Van Deuren, M., and Wetzels, J. F. (1998). The allopurinol hypersensitivity syndrome. Neth. J. Med. 52, 107-110.

Risso, A., Cosulich, M. E., Rubartelli, A., Mazza, M. R., and Bargellesi, A. (1989). MLR3 molecule is an activation antigen shared by human $\mathrm{B}, \mathrm{T}$ 
lymphocytes and $\mathrm{T}$ cell precursors. Eur. J. Immunol. 19, 323-328.

Rodnan, G. P., Robin, J. A., Tolchin, S. F., and Elion, G. B. (1975). Allopurinol and gouty hyperuricemia. Efficacy of a single daily dose. JAMA 231, 1143-1147.

Skudicky, D., Sliwa, K., Bergemann, A., Candy, G., and Sareli, P. (2000). Reduction in Fas/APO-1 plasma concentrations correlates with improvement in left ventricular function in patients with idiopathic dilated cardiomyopathy treated with pentoxifylline. Heart 84, 438-439.

Sliem, H., and Nasr, G. (2011). Left ventricular structure and function in prediabetic adults: relationship with insulin resistance. J. Cardiovasc. Dis. Res. 2, 23-28.

Sliwa, K., Woodiwiss, A., Candy, G., Badenhorst, D., Libhaber, C., Norton, G., Skudicky, D., and Sareli, P. (2002). Effects of pentoxifylline on cytokine profiles and left ventricular performance in patients with decompensated congestive heart failure secondary to idiopathic dilated cardiomyopathy. Am. J. Cardiol. 90, 1118-1122.

Sliwa, K., Woodiwiss, A., Kone, V. N., Candy, G., Badenhorst, D., Norton, G., Zambakides, C., Peters, F., and Essop, R. (2004). Therapy of ischemic cardiomyopathy with the immunomodulating agent pentoxifylline: results of a randomized study. Circulation 109, 750-755.

Smith, M. A., Blaker, P., Marinaki, A. M., Anderson, S. H., Irving, P. M., and Sanderson, J. D. (2012). Optimising outcome on thiopurines in inflammatory bowel disease by co-prescription of allopurinol. $\mathrm{J}$. Crohns Colitis 6, 905-912.

Stamp, L. K., Barclay, M. L., OandApos;Donnell, J. L., Zhang, M., Drake, J., Frampton, C., and Chapman, P. T. (2011). Relationship between serum urate and plasma oxypurinol in the management of gout: determination of minimum plasma oxypurinol concentration to achieve a target serum urate level. Clin. Pharmacol. Ther. 90, 392-398.

Stocker, S. L., Williams, K. M., Mclachlan, A. J., Graham, G. G., and Day, R. O. (2008). Pharmacokinetic and pharmacodynamic interaction between allopurinol and probenecid in healthy subjects. Clin. Pharmacokinet. 47, 111-118.

Torrance, H. L., Benders, M. J., Derks, J. B., Rademaker, C. M. A., Bos, A. F., Van Den Berg, P., Longini, M., Buonocore, G., Venegas, M., Baquero, H., Visser, G. H. A., and Van Bel, F. (2009). Maternal allopurinol during fetal hypoxia lowers cord blood levels of the brain injury marker S-100B. Pediatrics $124,350-357$.

Turnheim, K., Krivanek, P., and Oberbauer, R. (1999). Pharmacokinetics and pharmacodynamics of allopurinol in elderly and young subjects. Br. J. Clin. Pharmacol. 48, 501-509.

Van Dijk, A. J., Parvizi, N., Taverne, M. A., and Fink-Gremmels, J. (2008). Placental transfer and pharmacokinetics of allopurinol in late pregnant sows and their fetuses. J. Vet. Pharmacol. Ther. 31, 489-495.

Williams, M. S., and Kwon, J. (2004). $\mathrm{T}$ cell receptor stimulation, reactive oxygen species, and cell signaling. Free Radic. Biol. Med. 37, 1144-1151.

Yan, Z., and Banerjee, R. (2010). Redox remodeling as an immunoregulatory strategy. Biochemistry 49, 1059-1066.

Yan, Z., Garg, S. K., and Banerjee, R. (2010). Regulatory T cells interfere with glutathione metabolism in dendritic cells and T cells. J. Biol. Chem. 285, 41525-41532.

Yano, S., Yano, N., Rodriguez, N., Baek, J. H., Que, X., Yamamura, Y., and Kim, S. J. (1998). Suppression of intracellular hydrogen peroxide generation and catalase levels in
CD8+ T-lymphocytes from HIV+ individuals. Free Radic. Biol. Med. 24, 349-359.

Conflict of Interest Statement: The authors declare that the research was conducted in the absence of any commercial or financial relationships that could be construed as a potential conflict of interest.

Received: 21 June 2012; accepted: 04 September 2012; published online: 21 September 2012.

Citation: Pérez-Mazliah D, Albareda MC, Alvarez MG, Lococo B, Bertocchi GL, Petti M, Viotti RJ and Laucella SA (2012) Allopurinol reduces antigenspecific and polyclonal activation of human T cells. Front. Immun. 3:295. doi: 10.3389/fimmu.2012.00295

This article was submitted to Frontiers in Inflammation, a specialty of Frontiers in Immunology.

Copyright (c) 2012 Pérez-Mazliah, Albareda, Alvarez, Lococo, Bertocchi, Petti, Viotti and Laucella. This is an open-access article distributed under the terms of the Creative Commons Attribution License, which permits use, distribution and reproduction in other forums, provided the original authors and source are credited and subject to any copyright notices concerning any third-party graphics etc. 